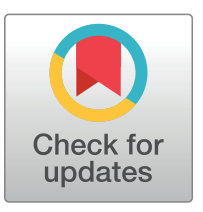

\section{G OPEn ACCESS}

Citation: Vidal I, Zheng Q, Hicks JL, Chen J, Platz EA, Trock BJ, et al. (2021) GSTP1 positive prostatic adenocarcinomas are more common in Black than White men in the United States. PLOS ONE 16(6): e0241934. https://doi.org/10.1371/journal. pone.0241934

Editor: Craig N. Robson, Northern Institute for Cancer Research, UNITED KINGDOM

Received: November 23, 2020

Accepted: May 28, 2021

Published: June 30, 2021

Peer Review History: PLOS recognizes the benefits of transparency in the peer review process; therefore, we enable the publication of all of the content of peer review and author responses alongside final, published articles. The editorial history of this article is available here: https://doi.org/10.1371/journal.pone.0241934

Copyright: ๑ 2021 Vidal et al. This is an open access article distributed under the terms of the Creative Commons Attribution License, which permits unrestricted use, distribution, and reproduction in any medium, provided the original author and source are credited.

Data Availability Statement: All relevant data are within the manuscript and its Supporting Information files.

RESEARCH ARTICLE

\title{
GSTP1 positive prostatic adenocarcinomas are more common in Black than White men in the United States
}

\begin{abstract}
Igor Vidal ${ }^{1}$, Qizhi Zheng ${ }^{1}$, Jessica L. Hicks ${ }^{1}$, Jiayu Chen $\oplus^{1}$, Elizabeth A. Platz $\oplus^{2,3,4}$, Bruce J. Trock ${ }^{2,3,5}$, Ibrahim Kulac $\circledast^{6}$, Javier A. Baena-Del Valle $\oplus^{7}$, Karen S. Sfanos $\circledast^{1,2,3,5,8}$, Sarah Ernst ${ }^{1}$, Tracy Jones ${ }^{1}$, Janielle P. Maynard $\oplus^{1}$, Stephanie A. Glavaris $\oplus^{5}$, William G. Nelson $\oplus^{1,2,3,5,8}$, Srinivasan Yegnasubramanian $\circledast^{1,2,3,8}$, Angelo M. De Marzo $\oplus^{1,2,3,5,8 *}$

1 Department of Pathology, The Johns Hopkins University School of Medicine, Baltimore, Maryland, United States of America, 2 The Sidney Kimmel Comprehensive Cancer Center at Johns Hopkins, Baltimore, Maryland, United States of America, 3 The Brady Urological Research Institute at Johns Hopkins, Baltimore, Maryland, United States of America, 4 Department of Epidemiology, The Johns Hopkins Bloomberg School of Public Health, Baltimore, Maryland, United States of America, 5 Department of Urology, The Johns Hopkins University School of Medicine, Baltimore, Maryland, United States of America, 6 Koc University, Istanbul, Turkey, 7 Fundación Santa Fe de Bogotá University Hospital, Bogotá, Colombia, 8 Department of Oncology, The Johns Hopkins University School of Medicine, Baltimore, Maryland, United States of America

*ademarz@jhmi.edu
\end{abstract}

\section{Abstract}

GSTP1 is a member of the Glutathione-S-transferase (GST) family silenced by CpG island DNA hypermethylation in $90-95 \%$ of prostate cancers. However, prostate cancers expressing GSTP1 have not been well characterized. We used immunohistochemistry against GSTP1 to examine 1673 primary prostatic adenocarcinomas on tissue microarrays (TMAs) with redundant sampling from the index tumor from prostatectomies. GSTP1 protein was positive in at least one TMA core in $7.7 \%$ of cases and in all TMA cores in $4.4 \%$ of cases. The percentage of adenocarcinomas from Black patients who had any GSTP1 positive TMA cores was $14.9 \%$, which was 2.5 times higher than the percentage from White patients (5.9\%; $\mathrm{P}<0.001)$. Further, the percentages of tumors from Black patients who had all TMA spots positive for GSTP1 (9.5\%) was 3-fold higher than the percentage from White patients (3.2\%; $\mathrm{P}<0.001)$. In terms of association with other molecular alterations, GSTP1 positivity was enriched in ERG positive cancers among Black men. By in situ hybridization, GSTP1 mRNA expression was concordant with protein staining, supporting the lack of silencing of at least some GSTP1 alleles in GSTP1-positive tumor cells. This is the first report revealing that GSTP1-positive prostate cancers are substantially over-represented among prostate cancers from Black compared to White men. This observation should prompt additional studies to determine whether GSTP1 positive cases represent a distinct molecular subtype of prostate cancer and whether GSTP1 expression could provide a biological underpinning for the observed disparate outcomes for Black men. 
Funding: This work was supported by $\mathrm{NIH/NCl}$ SPORE in Prostate Cancer: P50CA58236, and the $\mathrm{NIH} / \mathrm{NCl}$ U01 CA196390 for the Molecular and Cellular Characterization of Screen Detected Lesions (MCL), the U.S. Department of Defense Prostate Cancer Research Program (PCRP): W81XWH-18-2-0015. The Johns Hopkins Sidney Kimmel Comprehensive Cancer Center Oncology Tissue Services Laboratory supported by $\mathrm{NIH} / \mathrm{NCl}$ grant P30 CA006973.

Competing interests: Conflicts of interest: S.Y., W. G.N., and A.M.D. are paid consultants to Cepheid LLC, with whom they are developing epigenetic tests for prostate cancer. S.Y. has received sponsored research support from Cepheid for development and testing of prostate cancer epigenetic biomarkers. This arrangement has been reviewed and approved by the Johns Hopkins University in accordance with its conflict of interest policies. This does not alter our adherence to PLOS ONE policies on sharing data and materials.

\section{Introduction}

The pi class glutathione S transferase (encoded by the GSTP1 gene) is a member of the cytosolic superfamily of glutathione-S-transferases. These phase II detoxification enzymes catalyze the conjugation of glutathione to diverse endogenous and exogenous electrophiles [1]. In the prostate, GSTP1 is constitutively expressed at high levels in basal epithelial cells, variably expressed in luminal epithelial cells, and epigenetically silenced in approximately 90 to $95 \%$ of adenocarcinomas by somatic hypermethylation of its regulatory CpG island [2-5]. Hypermethylation of GSTP1 appears to occur early in prostatic carcinogenesis since it is already present in approximately $70 \%$ of high-grade PIN lesions [6,7], the presumed precursor of most invasive carcinomas, where it is silenced specifically in luminal epithelial cells $[7,8]$. Studies in human prostate cancer cells suggest a role for GSTP1 as a caretaker gene whose loss increases cell survival in response to protracted oxidative injury [9]. In mouse models of carcinogen exposure induced cancers of the lung and skin, Gstp1/2 behaves as a tumor suppressor [10,11]. In a mouse model of early prostate cancer development induced by human MYC, Gstp1/2 also functions as a tumor suppressor [12].

GSTP1 acts as a homodimer to catalyze reactions between reactive oxygen species, anti-cancer drugs or carcinogens, and glutathione, sometimes 'detoxifying' and at other times 'toxifying' the substrates [13]. By contrast to silencing GSTP1, an induction of expression of GSTP1 protein is used to detect early cancer formation in response to carcinogenic exposure in the rat liver [14]. Moreover, expression and overexpression of GSTP1 are common in several human tumor types, where it has been implicated in promoting resistance to a number of chemotherapeutic agents [15]. Although GSTP1 expression has been estimated to be maintained in 5-10\% of prostate cancer cases, little is known about the molecular and clinical features of these cases and only a few studies have directly asked the question of the frequency of positive GSTP1 Immunohistochemical (IHC) staining in prostate cancer [16,17].

Black men are more likely to develop prostate cancer than White men, and are more likely to have poor outcomes if diagnosed with the disease [18]. The reasons for the disparity are multifaceted, including inequities in access to high-quality prostate cancer screening, detection, diagnosis, and treatment. In addition, there appear to be at least some biological differences in disease pathogenesis and malignant progression, potentially based on associations of perceived race with genetic variation, or, as a result of different exposures. For example, when compared to prostate cancers from predominantly White men, prostate cancers from Black men contain fewer TMPRSS2-ERG fusions [19-22], fewer PTEN deletions [20-23], and more SPOP mutations [21,22].

In this study we comprehensively surveyed the frequency of GSTP1 protein expression in human clinical prostate cancers by IHC using tissue microarrays (TMAs). Our goal was to begin to determine whether GSTP1-positive prostate cancer represents a distinct molecular subtype, and, whether the prevalence of GSTP1-positivity differs between Black and White men.

\section{Materials and methods}

\section{Study population}

The study population consisted of 1673 patients who underwent radical prostatectomy (RRP) at a single center between 1993 and 2019, with an age range from 40 to 75 years old and whose prostatectomy tissue was arrayed across 45 TMA blocks. The cancers encompassed all Gleason grade groups and a spectrum of pathological stages. For IHC staining for GSTP1, we used the following TMA sets. TMA set 1 consists of prostatectomy tissue enriched for different Gleason 
grade groups and pathological stages from 476 cases operated on between 1997 and 2005 ( $\mathrm{N}=11$ TMA blocks). TMA set 2 consists of prostatectomy tissue from 726 patients operated on between 1993 to 2000 ( $\mathrm{N}=16$ TMA blocks) [24]. TMA set 3 consists of prostatectomy tissue from 343 Black and White men, operated on between 1993 and 2019 and matched on Gleason score, pathological stage and date of surgery within 2 years ( $\mathrm{N}=9$ TMA blocks) [25]. TMA set 4 is newly designed and consists of prostatectomy tissue from 353 men operated on between 2007 and 2015 from a case-cohort design ( $\mathrm{N}=9$ TMA blocks; detailed design to be described in a separate publication). These TMAs were all constructed as described $[24,26,27]$ from the index tumor (highest grade) with a 3-4 fold sampling redundancy. To compare IHC staining and the in situ hybridization assay for GSTP1 mRNA, we used a novel TMA (TMA set 5), which consists of prostatectomy tissue from 31 patients operated on less than 1 year before TMA construction in which TMA slides are stored at $-20^{\circ} \mathrm{C}$, which improves RNA quality for hybridizations [28]. All clinical and pathology data used for the study were obtained from the pathology archives of the Johns Hopkins. The Johns Hopkins University School of Medicine Institutional Review Board approved this study.

\section{IHC staining}

We analytically validated an automated IHC assay against human GSTP1 protein using wellknown cell lines and controls and human prostate cancer tissues using a mouse monoclonal antibody (Cell Signaling Technologies, \#3369) at 1:400 dilution on a Ventana DISCOVERY ULTRA Autostainer using the DISCOVERY anti-HQ HRP kit as described [8]. Cell line FFPE blocks were prepared and utilized as described $[29,30]$. LNCaP cells were negative and DU145 and PC3 prostate cancer cell lines were positive for GSTP1 protein as expected [2]. In a subset of the above TMAs, we also performed IHC staining for ERG (rabbit recombinant monoclonal antibody; ABCAM EPR3864, Cambridge, UK) and PTEN (rabbit monoclonal; Cell Signaling Technologies, Danvers, MA), which were performed in an automated assay on the Ventana DISCOVERY ULTRA using the DISCOVERY HQ+ Amp kit. Genetically validated cell line controls were used for antibody specificity for ERG (VCAP cells are positive and PC3, LNCaP and DU145 are negative) and PTEN (PC3 and LNCaP cells are negative and DU145 cells are positive) [31,32]. Immunostaining for p63 was carried out using the mouse monoclonal antibody (clone 4A4, Biocare Medical, Concord,CA, USA) as part of a singleplex stain [33] or as part of a cocktail [34] (PIN4 staining, Biocare Medical) on the Ventana DISCOVERY ULTRA platform.

\section{Slide scanning, image management and scoring}

Whole TMA slides were scanned on a Hamamatsu Nanozoomer, and imported into Concentriq (from Proscia). Composite images were exported from Concentriq and imported into and visualized in TMAJ [28]. For quality control of IHC staining in the TMA spots, we used the fact that a high fraction of non-neoplastic stromal cells routinely stained positively for GSTP1. We used these stromal cells as internal positive controls such that TMA cores that lacked any staining in tumor cells, and all stromal cells, were regarded as non-evaluable and were not included in the analyses. In another small subset of TMA cores, staining was very weak in intensity in both the tumor cells and stromal cells and these were also considered equivocal in terms of staining quality and were not included. Together, this poor quality staining and uninterpretable staining in weak cases comprised $\sim 1 \%$ of tissue cores with carcinoma.

Scanned TMA core images were evaluated for the presence of carcinoma by two pathologists with expertise in prostate cancer (I.V. and A.M.D.). Each TMA core containing carcinoma was evaluated for GSTP1 staining positivity using a two-tiered scoring strategy in which 
any tumor cell staining above background levels (nuclear, cytoplasmic, or both) were considered positive. All others were considered negative. Cases in which there was positive cancer cell staining for GSTP1 protein were categorized in two ways: any patient who had 1) any TMA spot with some positive tumor cell staining or 2) all TMA spots with some positive tumor cells staining; all other cases were considered GSTP1-negative.

In a subset of cases we also assessed ERG and PTEN to determine co-occurrence of GSTP1 positivity with ERG positivity and PTEN loss. ERG was considered positive for a given patient's tumor if any cancer cells on any TMA cores with cancer were positive and PTEN was considered lost if any TMA cores contained any tumor cells with complete PTEN absence of staining.

\section{In situ hybridization for GSTP1 mRNA}

We developed a novel in situ hybridization assay for GSTP1 mRNA using ACD RNAscope, which we analytically validated (Probe-Hs-GSTP1 Cat No. 453221, kit version 2.5 manual assay according to manufacturer's recommendations) using cell lines with known GSTP1 expression status for positive and negative controls as described (S1 Fig) [8,28]. Briefly, FFPE tissue slides were baked at $60^{\circ} \mathrm{C}$ for 1 hour followed by deparaffinization in $100 \%$ xylene twice for 5 minutes each and two changes of $100 \%$ alcohol. The slides were treated with endogenous peroxidase blocking pretreatment reagent and then incubated for 15 minutes in a boiling $1 \times$ Pretreat 2 reagent (ACD) and then treated with protease digestion buffer (III, Cat. 322337) for 30 minutes at $40^{\circ} \mathrm{C}$. The slides were incubated with a RNAscope target probe as follows: for 2 hours at $40^{\circ} \mathrm{C}$, followed by signal amplification. 3,3'-Diaminobenzidine (DAB) was used for colorimetric detection for 10 minutes at room temperature. LNCaP, PC3 and DU145 prostate cancer cells were maintained as described [30]. MDA-PCA-2b cells were maintained in F-12K media containing $20 \%$ non heat-inactivated FBS, $25 \mathrm{ng} / \mathrm{ml}$ cholera toxin (Sigma cat. No. C8052), $10 \mathrm{ng} / \mathrm{ml}$ mouse Epidermal Growth Factor (Corning cat. No. 354010), $0.005 \mathrm{mM}$ phosphoethanolamine (Sigma cat. No. P0503), 100 pg/ml hydrocortisone (Sigma cat. No. H0135), $45 \mathrm{nM}$ sodium selenite (Sigma cat\# 9133) and $0.005 \mathrm{mg} / \mathrm{ml}$ human recombinant insulin (Life Technologies cat\# $12585-014$ ) at $37^{\circ} \mathrm{C}$ and $5 \% \mathrm{CO} 2$. All cell lines were obtained from ATCC (Manassas, VA). All cell lines were authenticated using short tandem repeat profiling by the Genetic Resources Core Facility at The Johns Hopkins University School of Medicine.

\section{Statistical analysis}

Data were tabulated and statistical tests were performed using Stata 15 for Mac OS. The primary analysis for comparisons between groups used GSTP1 protein positivity status for each patient, either any TMA core positive or all cores positive (Tables 2-8). Tests for differences in proportions for any TMA core or all TMA cores positive for GSTP1 protein between Black and White men, between ERG positive and negative men, and between PTEN absent and PTEN present men were performed with the Pearson Chi2 test. Tests for trends for the proportion of men who were GSTP1 protein positive across Gleason grade groups and pathological stages were performed using the Cuzick's nonparametric trend test across ordered groups.

\section{Results}

We applied an analytically validated automated IHC assay to evaluate GSTP1 protein expression [8] in a series of TMAs constructed from patients with clinically localized primary prostatic adenocarcinomas. A total of 5,757 TMA cores containing prostatic adenocarcinoma from 1,673 patients were evaluable for GSTP1 protein scoring by IHC. These consisted of 1,197 
Table 1. Total number of patients and TMA spots with carcinoma.

\begin{tabular}{l|c|c}
\hline Race & No. of patients & No. of evaluable TMA cores with carcinoma \\
\hline Black & 336 & 1197 \\
\hline White & 1337 & 4560 \\
\hline Total & $\mathbf{1 6 7 3}$ & $\mathbf{5 7 5 7}$ \\
\hline
\end{tabular}

https://doi.org/10.1371/journal.pone.0241934.t001

cores from 336 patients that self-identified as Black (mean age $=58.4$; SD 6.6) and 4,560 TMA cores from 1,337 patients that self-identified as White (mean age $=59.3$; SD 6.5) (Table 1).

As expected, carcinoma cells in most prostatic adenocarcinomas were completely negative for GSTP1 protein (92.3\%; Table 2). In a subset of cases, however, some or all cancer cells stained positively for GSTP1. While some cases were uniformly positive for GSTP1, in other cases containing GSTP1 positive tumor cells, we often observed heterogeneity in staining in terms of both cell number and staining intensity. This variability occurred among cancer cells at times within a given TMA core, between a man's TMA cores, and between men. Fig $1 \mathrm{dem}$ onstrates representative images of these patterns of staining. Overall, $7.7 \%$ of cases contained GSTP1 positive cancer cells in a subset of TMA cores, and 4.5\% had GSTP1 positive cancer cells in all TMA cores.

The percentage of adenocarcinomas from Black patients who had any GSTP1 positive cancer-containing TMA cores was $14.9 \%$, which was 2.5 times higher than the percentage of cases with any GSTP1 positive cancer-containing cores from White patients $(5.9 \%$; $>0.001)$ (Table 2). Further, the percentages of tumors from Black patients who had all TMA spots with cancer cells staining positive for GSTP1 (9.5\%) was 3-fold higher than the percentage of tumors from White patients $(3.2 \% ; \mathrm{P}<0.001)$ (Table 2). We confirmed that the number of evaluable TMA cores with carcinoma was similar among tumors from Black and White men, and also ran sensitivity analysis restricted to men with the same number of evaluable cores and similar results were obtained.

Cases with any or all TMA cores with cancer cells staining positive for GSTP1 occurred across all Gleason grade groups and stages, and the higher percentage of cases from Black patients positive for GSTP1 was apparent among all grade groups except in grade group 5 (Table 3 ) and except in stage group 3 (Table 4). In Black but not White patients, the percentage of cases with any core positive was non-significantly decreased with increasing Gleason grade group (Table 3 ) and significantly decreased with increasing pathological stage (Table 4).

A subset of TMAs ( $\mathrm{N}=16$ TMA blocks) were stained for ERG protein by IHC, which tightly correlates with TMPRSS2-ERG gene fusions [35,36]. TMPRSS2-ERG gene fusions are the most common form of ETS gene family member fusions in prostate cancer and are mutually exclusive with other ETS family member fusions and a number of other somatic molecular alterations in prostate cancer, such as SPOP mutations or SPINK overexpression [37].

Table 2. GSTP1 protein staining in cancer cells in Black and White patients.

\begin{tabular}{l|l|l|l|l|l|l|l|l}
\hline \multicolumn{3}{l}{ Any cores positive } & \multicolumn{3}{l}{} & \multicolumn{2}{l}{ All cores positive } \\
\hline Race & No & Yes & Total & P Value & No & Yes & Total & P Value \\
\hline Black & $286(85.1 \%)$ & $50(14.9 \%)$ & 336 & $304(90.5 \%)$ & $32(9.5 \%)$ & 338 & \\
\hline White & $1,258(94.1 \%)$ & $79(5.9 \%)$ & 1,337 & $1,294(96.8 \%)$ & $43(3.2 \%)$ & 1,339 & \\
\hline Total & $\mathbf{1 , 5 4 4}$ & $\mathbf{1 2 9}$ & $\mathbf{1 , 6 7 3}$ & $<\mathbf{0 . 0 0 1}$ & $\mathbf{1 , 5 9 8}$ & $\mathbf{7 5}$ & $\mathbf{1 , 6 7 3}$ & $<\mathbf{0 . 0 0 1}$ \\
\hline
\end{tabular}

$\mathrm{N}$ in each cell represents number of patients.

https://doi.org/10.1371/journal.pone.0241934.t002 
A

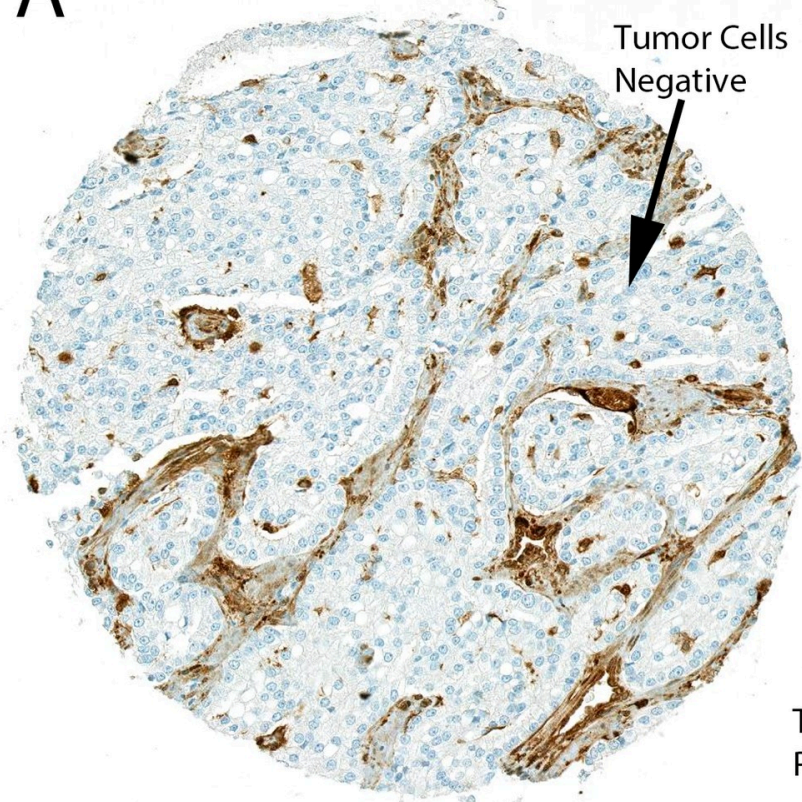

B

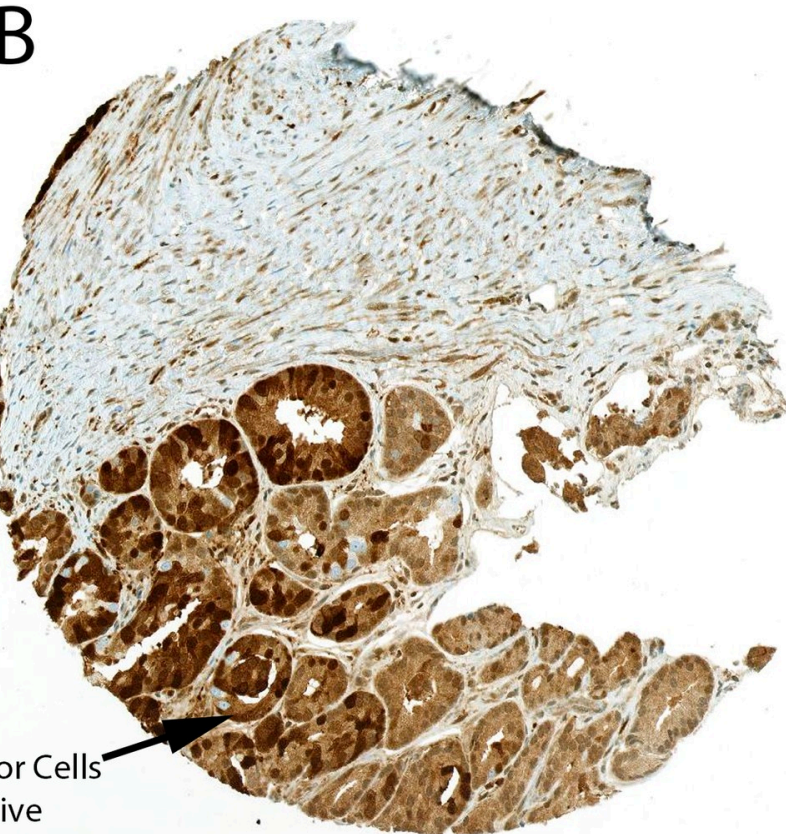

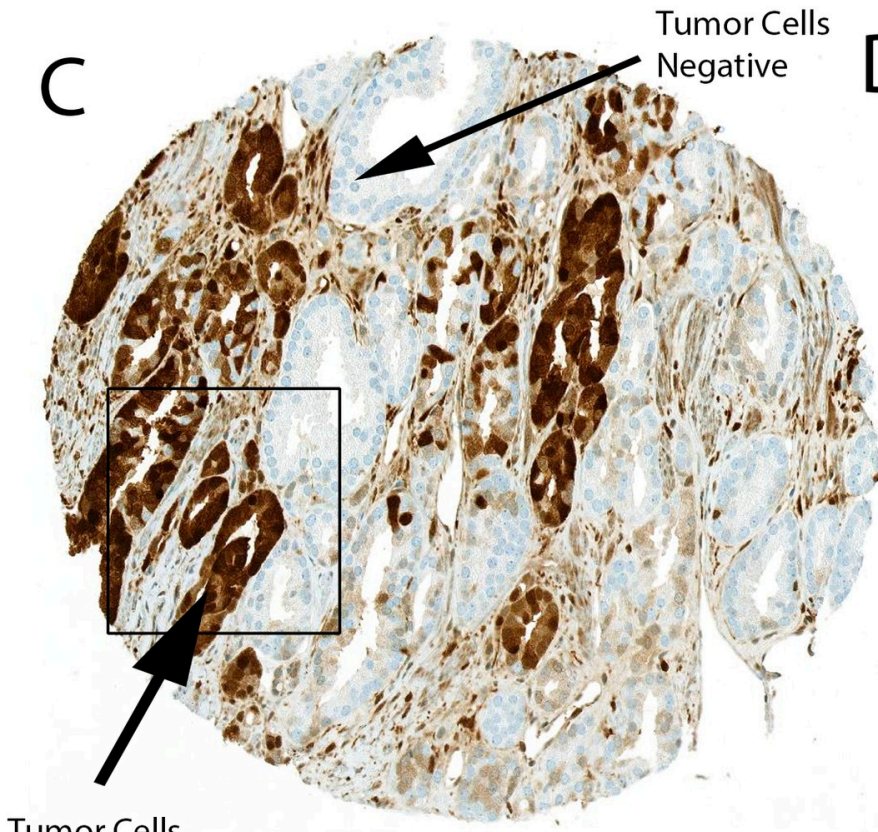

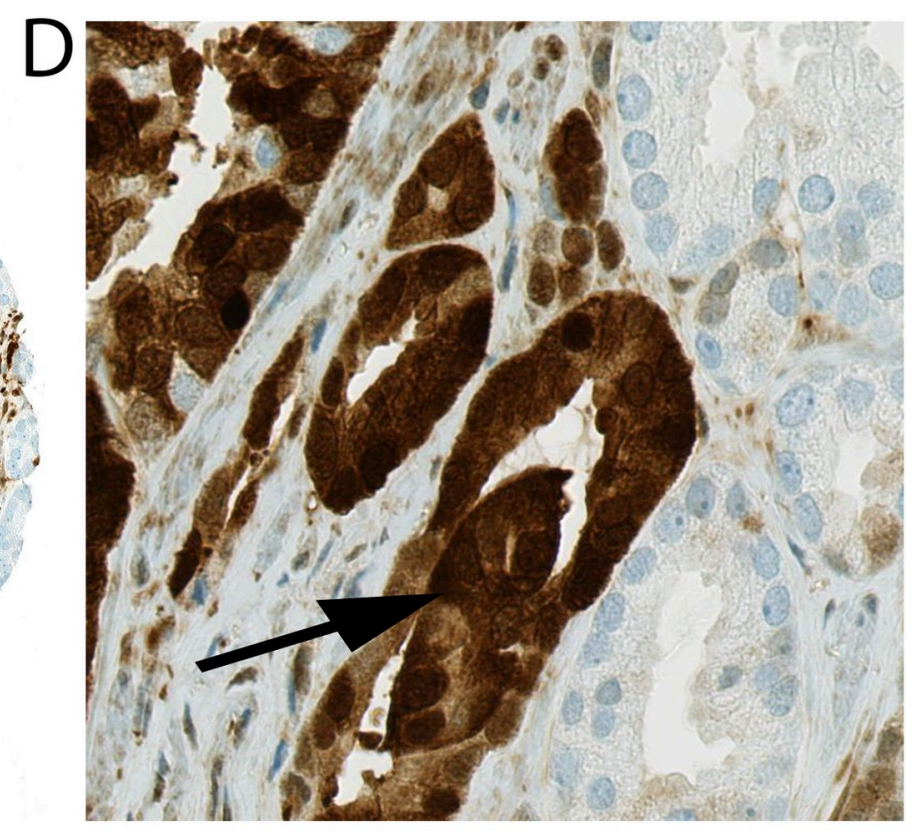

Positive

Fig 1. Patterns of GSTP1 protein staining. Medium power views of TMA spots containing adenocarcinoma with examples of all tumor cells being GSTP1-negative (A), all tumor cells being GSTP1-positive (B), and a spot with heterogeneous mosaic staining with some cells staining positively and some negatively $(\mathrm{C})$. In all examples, there is abundant stromal cell staining that is most apparent in (A) in between tumor nests. Original magnification $\mathrm{x}$ 100. (D) Higher power view of boxed regions in (C).

https://doi.org/10.1371/journal.pone.0241934.g001

Therefore, prostate cancers harboring $E R G$ gene fusions are considered a distinct molecular subtype of prostate cancer. In this TMA subset, the percentage of tumors from Black patients with any TMA core positive for ERG was significantly lower than for tumors from White patients, consistent with prior reports [19] (Table 6). 
Table 3. GSTP1 protein staining by Gleason grade groups in Black and White patients.

\begin{tabular}{|c|c|c|c|c|c|c|c|c|}
\hline \multirow[b]{3}{*}{ Grade group } & \multicolumn{2}{|l|}{ Black } & & & \multicolumn{2}{|l|}{ White } & \multirow[b]{3}{*}{ Total } & \multirow[b]{3}{*}{ P Value } \\
\hline & \multicolumn{2}{|c|}{ Any cores positive } & \multirow[b]{2}{*}{ Total } & \multirow[b]{2}{*}{ P Value } & \multicolumn{2}{|c|}{ Any cores positive } & & \\
\hline & No & Yes & & & No & Yes & & \\
\hline $1(\mathrm{GS} 6)$ & $68(77.3 \%)$ & $20(22.7 \%)$ & $88(100 \%)$ & & $230(93.1 \%)$ & $17(6.9 \%)$ & $247(100 \%)$ & \\
\hline $2(\mathrm{GS} 3+4=7)$ & $97(86.6 \%)$ & $15(13.4 \%)$ & $112(100 \%)$ & & $448(94.7)$ & $25(5.3 \%)$ & $473(100 \%)$ & \\
\hline $3(\mathrm{GS} 4+3=7)$ & $43(89.6 \%)$ & $5(10.4 \%)$ & $48(100 \%)$ & & $287(95.7 \%)$ & $13(4.3 \%)$ & $300(100 \%)$ & \\
\hline $4(\mathrm{GS} 8)$ & $24(82.8 \%)$ & $5(17.2 \%)$ & $29(100 \%)$ & & $150(93.2 \%)$ & $11(6.8 \%)$ & $161(100 \%)$ & \\
\hline 5 (GS 9-10) & $54(91.5 \%)$ & $5(8.5 \%)$ & $59(100 \%)$ & & $143(91.7 \%)$ & $13(8.3 \%)$ & $156(100 \%)$ & \\
\hline \multirow[t]{2}{*}{ Total } & $286(84.9 \%)$ & $50(14.8 \%)$ & $336(100 \%)$ & 0.039 & $1,258(94.0 \%)$ & $79(5.9 \%)$ & $1,337(100 \%)$ & 0.50 \\
\hline & \multicolumn{2}{|c|}{ All cores positive } & & & \multicolumn{2}{|c|}{ All cores positive } & & \\
\hline Grade group & No & Yes & Total & P Value & No & Yes & Total & P Value \\
\hline $1(\mathrm{GS} 6)$ & $74(84 \%)$ & $14(15.9 \%)$ & $88(100 \%)$ & & $238(96.3 \%)$ & $9(3.6 \%)$ & $247(100 \%)$ & \\
\hline $2(\mathrm{GS} 3+4=7)$ & $106(94.6 \%)$ & $6(5.4 \%)$ & $112(100 \%)$ & & $460(97.3 \%)$ & $13(2.8 \%)$ & $473(100 \%)$ & \\
\hline $3(\mathrm{GS} 4+3=7)$ & $44(91.7 \%)$ & $4(8.3 \%)$ & $48(100 \%)$ & & $294(98.0 \%)$ & $6(2 \%)$ & $300(100 \%)$ & \\
\hline 4 (GS 8) & $24(82.8 \%)$ & $5(17.2 \%)$ & $29(100 \%)$ & & $152(94.4 \%)$ & $9(5.6 \%)$ & $161(100 \%)$ & \\
\hline 5 (GS 9-10) & $56(94.9 \%)$ & $3(5.1 \%)$ & $61(100 \%)$ & & $150(96.2 \%)$ & $6(3.9 \%)$ & $156(100 \%)$ & \\
\hline Total & $304(90.5 \%)$ & $32(9.5 \%)$ & $338(100 \%)$ & 0.21 & $1294(96.8 \%)$ & $43(3.2 \%)$ & $1,337(100 \%)$ & 0.46 \\
\hline
\end{tabular}

$\mathrm{N}$ in each cell represents number of patients.

https://doi.org/10.1371/journal.pone.0241934.t003

When not considering race, the percentage of cases with any TMA spot or all TMA spots with cancer cells staining positive for GSTP1 was lower in those who were ERG+ than ERG(Table 5). This same pattern was observed when examining White patients only (Table 6, any TMA spot positive). In Black patients, the opposite pattern was observed; the percentage of any TMA spot positive for GSTP1 expressing cancer was higher in men who were ERG positive than ERG negative. The percentage of patients with ERG positive cancers that were also GSTP1 positive was $23.1 \%$ in Black men, but only $5.1 \%$ in White men, a difference that was statistically significant (Table $6, \mathrm{P}=0.001$ ). In contrast, the percentage of patients with $E R G$

Table 4. GSTP1 protein staining by pathological stage in Black and White patients.

\begin{tabular}{|c|c|c|c|c|c|c|c|c|}
\hline \multirow[b]{3}{*}{ Stage } & \multicolumn{2}{|l|}{ Black } & & & \multicolumn{2}{|l|}{ White } & \multirow[b]{3}{*}{ Total } & \multirow[b]{3}{*}{ P Value } \\
\hline & \multicolumn{2}{|c|}{ Any cores positive } & \multirow[b]{2}{*}{ Total } & \multirow[b]{2}{*}{ P Value } & \multicolumn{2}{|c|}{ Any cores positive } & & \\
\hline & No & Yes & & & No & Yes & & \\
\hline 1 & $129(78.7 \%)$ & $35(21.3 \%)$ & 164 & & $459(93.1 \%)$ & $34(6.9 \%)$ & 493 & \\
\hline 2 & $87(89.7 \%)$ & $10(10.3 \%)$ & 97 & & $507(96.0 \%)$ & $21(4.0 \%)$ & 528 & \\
\hline 3 & $69(93.2 \%)$ & $5(6.8 \%)$ & 74 & & $287(92.3 \%)$ & $24(7.7 \%)$ & 311 & \\
\hline \multirow[t]{2}{*}{ Total } & $285(85.1 \%)$ & $50(14.9 \%)$ & 335 & $<0.004$ & $1253(94 \%)$ & $79(5.9 \%)$ & 1332 & 0.045 \\
\hline & \multicolumn{2}{|c|}{ All cores positive } & & & \multicolumn{2}{|c|}{ All cores positive } & & \\
\hline Stage & No & Yes & Total & P Value & No & Yes & Total & P Value \\
\hline 1 & $143(87.2 \%)$ & $21(12.8 \%)$ & 164 & & $476(96.6 \%)$ & $17(3.5 \%)$ & 493 & \\
\hline 2 & $91(93.8 \%)$ & $6(6.2 \%)$ & 97 & & $515(97.5 \%)$ & $13(2.5 \%)$ & 528 & \\
\hline 3 & $69(93.2 \%)$ & $5(6.8 \%)$ & 74 & & $298(95.8 \%)$ & $13(4.2 \%)$ & 311 & \\
\hline Total & $303(90.5 \%)$ & $32(9.5 \%)$ & 335 & 0.139 & $1289(96.8 \%)$ & $43(3.2 \%)$ & 1332 & 0.373 \\
\hline
\end{tabular}

Stage groups: 1 = "Organ Confined"-T2N0; 2 -"Extraprostatic Extension"-T3aN0; 3 = Seminal Vesicle Invasion or Pelvic Lymph Node Metastasis-T3BN0 or any N1 (AJCC 2007 staging criteria). $\mathrm{N}$ in each cell represents number of patients.

https://doi.org/10.1371/journal.pone.0241934.t004 
Table 5. GSTP1 protein staining by ERG status overall.

\begin{tabular}{l|c|c|c|c}
\hline & \multicolumn{3}{|c}{ ERG expression } & \\
\hline GSTP1 any TMA spot positive & Negative & Positive & Total & P Value \\
\hline No & $238(89.5 \%)$ & $189(92.6 \%)$ & 427 & \\
\hline Yes & $28(10.5 \%)$ & $15(7.4 \%)$ & 43 & 0.24 \\
\hline Total & $\mathbf{2 6 6}$ & $\mathbf{2 0 4}$ & $\mathbf{4 7 0}$ & \\
\hline GSTP1 all TMA spots positive & & & & \\
\hline No & $247(92.9 \%)$ & $197(96.6 \%)$ & 444 & \\
\hline Yes & $19(7.1 \%)$ & $7(3.4 \%)$ & 26 & 0.08 \\
\hline Total & $\mathbf{2 6 6}$ & $\mathbf{2 0 4}$ & $\mathbf{4 7 0}$ & \\
\hline
\end{tabular}

https://doi.org/10.1371/journal.pone.0241934.t005

negative cancers that were GSTP1 positive was more similar in Black (12.9\%) and White (9.4\%) patients (Table 6, $\mathrm{P}=0.38$ ).

A subset of TMAs $(\mathrm{N}=16)$ was also stained by IHC for PTEN, which is a known tumor suppressor in prostate cancer, whose loss is associated with disease progression [23]. Prior work has also found a lower fraction of prostatic carcinomas from Black patients with PTEN loss than carcinomas from White patients [20,21], which we observed here (22.5\% PTEN loss for Black patients and $34.9 \%$ PTEN loss for White patients). When not considering race, the percentage of patients with any GSTP1-positive TMA spot appeared to be lower in men with any PTEN loss than with PTEN intact (6.6\% compared with 10.3\%), but this difference was not statistically significant (Table 7). However, stratifying by race, the percentage of any TMA spot with cancer cells staining positive for GSTP1 was comparable in those with PTEN loss and PTEN intact in Black men and in White men (Table 8). The percentage of patients who had both PTEN loss and were GSTP1 positive was $12.0 \%$ in Black men, but only $5.6 \%$ in White men; this difference was not statistically significant (Table $8, \mathrm{P}=0.24$ ). These percentages were similar to those in those who had both PTEN intact and were GSTP1 positive, with $16.5 \%$ in Black men and $8.1 \%$ in White men; this difference was statistically significant (Table 8, $\mathrm{P}=0.029$ ).

Rare cases of prostate cancer have been reported that are strongly positive for nuclear p63 staining [33,38-40], and these cases tend to express GSTP1, and at times lack GSTP1 GpG island methylation [33]. We asked whether GSTP1 positive cases in the current study were ever positive for p63 nuclear staining. P63 IHC staining was available for 22 of the cases across 6 of the TMA blocks that stained positively for GSTP1 that have also been stained in our laboratory for p63; none of these cases $(0 / 22)$ were positive for nuclear p63 staining. We conclude that, while many p63-positive cancers are also positive for GSTP1 [33], most GSTP1-positive cancers are not p63-positive.

To test whether samples with GSTP1 positive protein staining also contained GSTP1 mRNA expression, we developed an ACD RNAscope in situ hybridization assay. We tested the

Table 6. GSTP1 protein staining by ERG status in Black and White patients.

\begin{tabular}{|c|c|c|c|c|c|c|c|c|}
\hline \multirow[b]{3}{*}{ GSTP1 any TMA spot positive } & \multicolumn{2}{|c|}{ ERG Positive } & \multirow[b]{3}{*}{ Total } & \multirow[b]{3}{*}{ P Value* } & \multicolumn{2}{|c|}{ ERG Negative } & \multirow[b]{3}{*}{ Total } & \multirow[b]{3}{*}{ P Value } \\
\hline & \multicolumn{2}{|c|}{ Race } & & & \multicolumn{2}{|l|}{ Race } & & \\
\hline & Black & White & & & Black & White & & \\
\hline No & $20(76.9)$ & $169(94.9 \%)$ & $189(92.6)$ & & $74(87.1 \%)$ & $164(90.6 \%)$ & $238(89.5 \%)$ & \\
\hline Yes & $6(23.1 \%)$ & $9(5.1 \%)$ & $15(7.4 \%)$ & 0.001 & $11(12.9 \%)$ & $17(9.4 \%)$ & $28(10.5 \%)$ & 0.38 \\
\hline Total & 26 & 178 & 204 & & 85 & 181 & 266 & \\
\hline
\end{tabular}

https://doi.org/10.1371/journal.pone.0241934.t006 
Table 7. GSTP1 protein staining by PTEN loss overall.

\begin{tabular}{l|c|c|c}
\hline & \multicolumn{3}{|c}{ PTEN status } \\
\hline GSTP1 any TMA spot positive & Loss (any) & Intact & Total \\
\hline No & $141(93.4 \%)$ & $287(89.7 \%)$ & 428 \\
\hline Yes & $10(6.6 \%)$ & $33(10.3 \%)$ & 43 \\
\hline Total & $\mathbf{1 5 1}$ & $\mathbf{3 2 0}$ & $\mathbf{4 7 1}$ \\
\hline
\end{tabular}

$\mathrm{P}=0.19$.

https://doi.org/10.1371/journal.pone.0241934.t007

hybridization reaction on cell lines and found that, as expected, PC 3 cells and DU145 cells were positive and LNCaP cells were negative [2] (Fig 2). MDA-PCa-2b cells, which were derived from an African American patient, were negative for GSTP1 mRNA (Fig 2) and protein (S1 Fig). In normal-appearing human prostate tissue, GSTP1 protein is consistently highly expressed in basal cells, with much lower and variable expression in normal appearing luminal cells. Furthermore, the expression is highly elevated in many of the intermediate luminal cells present in the atrophic epithelium of proliferative inflammatory atrophy [7,41]. Using standard slides from RRP specimens we found a similar pattern of hybridization signals for the GSTP1 ACD RNAscope probe set. There were also strong signals found in regions of the urethra as well as ejaculatory ducts, which is consistent with prior studies on GSTP1 protein [42] (Fig 2). Since RNAscope assays perform less robustly on older prostate cancer specimens [28], we performed in situ hybridization for GSTP1 mRNA and IHC using a "recent case" TMA consisting of an array from 31 RRP cases (TMA set 5). We found 2 cases positive for GSTP1 protein by IHC $(2 / 31=6.5 \%)$ and the same cases were also positive for GSTP1 mRNA; all cases staining negatively for GSTP1 protein were also negative for GSTP1 mRNA, giving a $100 \%$ concordance. We also performed IHC and in situ hybridization for GSTP1 mRNA on a number of standard slides from prostatectomy specimens and found an example that was heterogeneous for GSTP1 protein in the tumor. Fig 3 shows a region from this case that shows tight concordance between GSTP1 protein and mRNA expression.

\section{Discussion}

In this study, we used a large number of primary untreated prostate cancer cases from prostatectomies $(\mathrm{N}=1673)$ to estimate the percentage of prostatic adenocarcinomas that are positive for GSTP1 protein by IHC. We found an overall rate of any positive staining in cancer foci of $7.7 \%$. Interestingly, we also found that GSTP1-positive carcinomas were often heterogeneous for GSTP1 protein (41\%). In situ hybridization for GSTP1 mRNA showed that the increased protein in the GSTP1-positive cases likely occurred through transcriptional upregulation, suggested by the tight correlation between the protein and mRNA levels. For the first time, we report that GSTP1-positive cases are significantly more common in prostatic adenocarcinomas from Black patients compared with White patients (2.5-3 fold).

Table 8. GSTP1 protein staining by PTEN loss in Black and White patients.

\begin{tabular}{l|l|l|l|l|l|l|l|l|l|}
\hline & \multicolumn{2}{l|}{ RTEN Loss (any) } & & \multicolumn{3}{c}{ PTEN Intact } \\
\hline & \multicolumn{3}{|c|}{ Race } & & \multicolumn{3}{c}{ Race } \\
\hline GSTP1 any positive & Black & White & Total & P Value & GSTP1 any positive & Black & White & Total & P Value \\
\hline No & $22(88 \%)$ & $119(94.4 \%)$ & 141 & & No & $71(83.5 \%)$ & $216(91.9)$ & 287 & \\
\hline Yes & $3(12 \%)$ & $7(5.6 \%)$ & 10 & & Yes & $14(16.5 \%)$ & $19(8.1 \%)$ & 33 & \\
\hline Total & 25 & 126 & 151 & 0.24 & Total & 85 & 235 & 320 & 0.029 \\
\hline
\end{tabular}

https://doi.org/10.1371/journal.pone.0241934.t008 


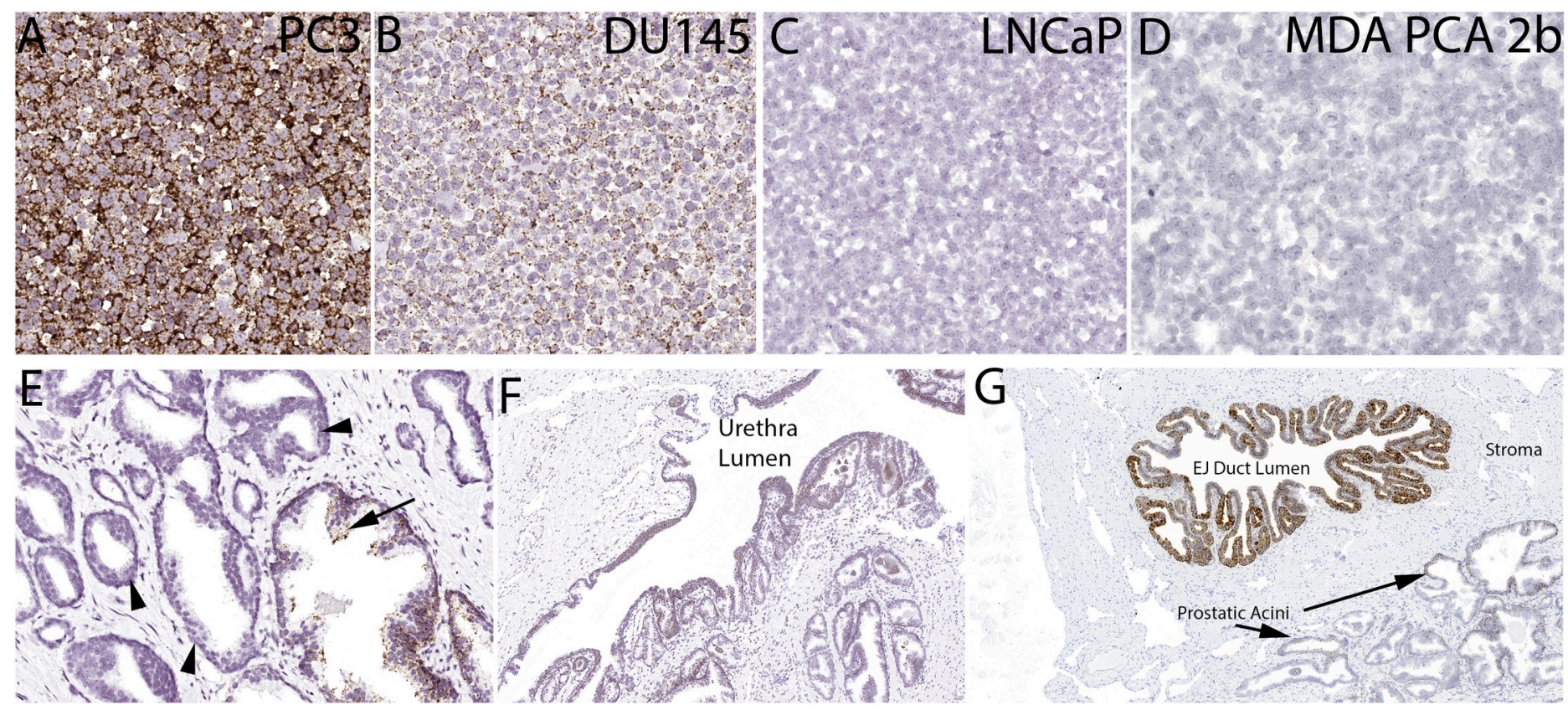

Fig 2. In situ hybridization for GSTP1 mRNA in cell lines (A-D) and benign prostate (E-G). EJ duct lumen indicates ejaculatory duct lumen.

https://doi.org/10.1371/journal.pone.0241934.g002

Given the difference in the percentage of GSTP1 positive cases by race, the current findings raise the question of whether GSTP1 positive cases represent a distinct molecular subtype of this disease. Interestingly, we found that the increase in GSTP1-positive cancers in Black men was greater in ERG-positive cases. This is of interest because prostate adenocarcinomas from Black men harbor ERG gene rearrangements less frequently than those from White men. In terms of PTEN, there was a similar increase in the percentage of GSTP1-positive cases regardless of PTEN status in Black patients.

Genomics studies of prostate cancers over the last several years have revealed the long tail of molecular alterations that can lead to cancer and influence disease progression and drug
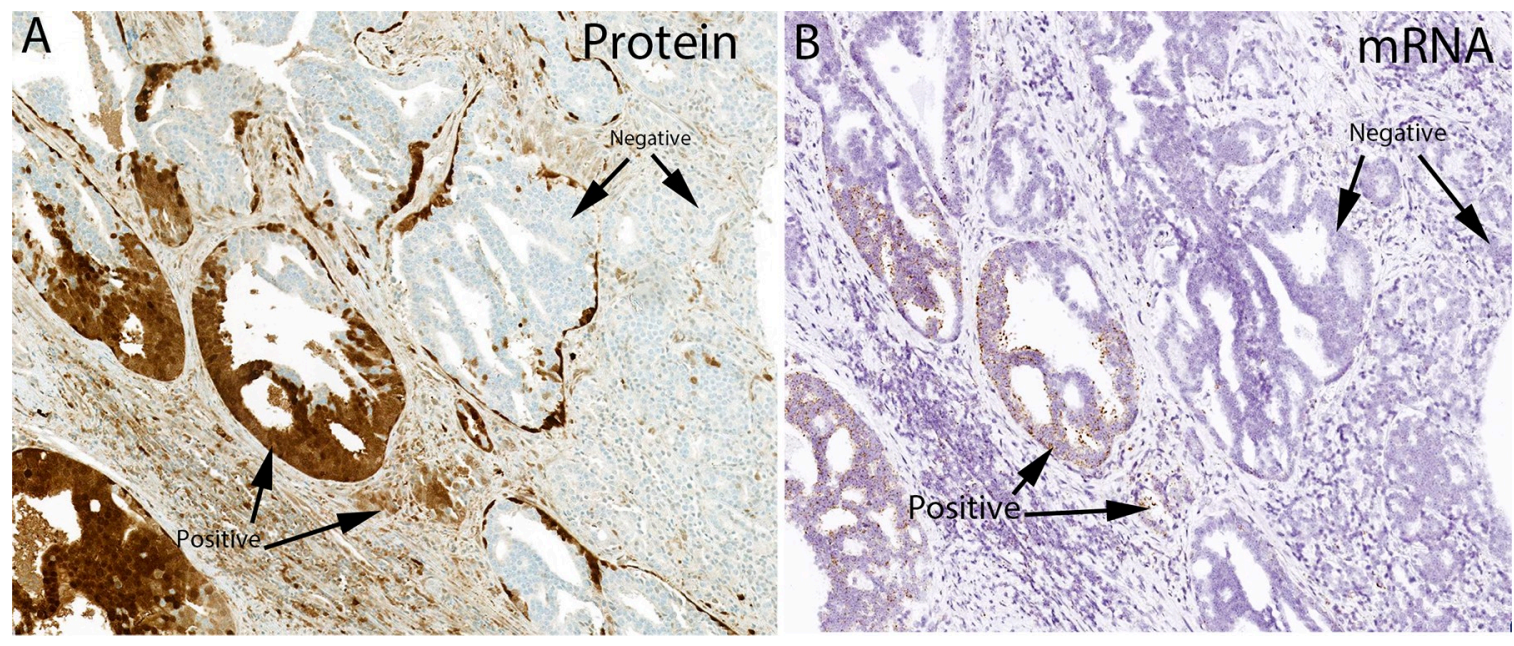

Fig 3. Concordance between in situ hybridization and IHC for GSTP1 in a heterogeneous prostate cancer case.

https://doi.org/10.1371/journal.pone.0241934.g003 
resistance [43-48]. These long tail events include low frequency germline and/or somatic molecular alterations involved in DNA repair (e.g., MMR defects caused by 1 of 4 different genes, BRCA2, ATM and CDK12). Other low frequency events considered important include FOXA1 mutations, IDH1/2 mutations, and mutations in a number of genes that affect epigenetic chromatin modifications. Given the large breadth of molecular alterations in prostate cancer, additional studies with larger numbers of patients are required to determine whether GSTP1 positive cases represent a distinct molecular subtype of prostate cancer.

In terms of disease aggressiveness, the percentage of men whose tumors were GSTP1- positive tended to decrease with increasing grade and stage in Black men, but not in White men (Tables 3 and 4). Thus, the increased frequency of GSTP1-positive cancers in Black versus White men occurred in low and intermediate grade and stage cancers only (Tables 3 and 4).

In terms of patient outcomes, in a series of 640 cases stained by IHC, there was no prognostic significance in univariate analysis for GSTP1 status [16]. Additional studies are underway to determine whether GSTP1 positive cases differ in terms of rates of biochemical recurrence, metastatic disease and deaths due to prostate cancer. Further, it will be of interest to determine whether GSTP1 status is related to response to therapies such as androgen deprivation, radiation, or chemotherapy and whether there are differences in the percentage of cases that are GSTP1 positive in metastatic castration sensitive and castration resistant prostate cancers. A recent study reported an association of BMI1 expression to the propensity of metastatic disease in prostate cancer in African-American men [49] and it will be interesting to correlate GSTP1 expression with that of BMI1 in future studies, including how each may contribute to the development of metastatic disease.

In terms of prostate cancer etiology, major risk factors are ancestry, family history and age. In terms of environmental exposures, at present, the fraction of prostate cancers attributable to known exposures remains quite low [50]. A limitation of our current study is that we have not determined whether men with prostate cancer that are GSTP1 positive, whether they be from Black or White men, have had different exposures than men with prostate cancers that are GSTP1 negative. Additional studies from population-based cohort studies with extensive prediagnosis exposure information are required to address this important issue and the potential racial disparity in prostate cancer burden. Also, a further limitation is that in our study we used self-identified race, which is not a biological measure; thus, future studies to include genotyping measures of percent African ancestry could perhaps help in determining whether GSTP1 expression status may be different as a result of genetic differences and/or environmental exposures or both.

To determine whether there is a different etiology for prostate cancers developing in Black versus White patients, gene expression studies can be instructive. A number of studies [21,5153], albeit not all [54], have reported increases in inflammatory cytokine signaling in tumors from men of African descent. While inflammatory signaling and altered inflammatory cell infiltrates in the tumor microenvironment may occur during any and all temporal phases of cancer development and progression, we have previously postulated that chronic long standing inflammation may lead to prostate cancer most likely via lesions we termed proliferative inflammatory atrophy $[41,55,56]$. Interestingly, in regions of PIA, there appears to be an induction of GSTP1 in luminal cells, which we refer to as intermediate luminal cells [41,56,57]; with progression to PIN or adenocarcinoma accompanied by CpG island hypermethylation and loss of expression [7]. In terms of GSTP1 positive prostate cancer, it is possible that some cases arise after induction of GSTP1 in luminal cells and without silencing the gene. Martignano et al. found a strong correlation with GSTP1 CpG island hypermethylation and GSTP1 protein status by IHC [17]. Another limitation of our study is that at present we do not know whether the expression of GSTP1 protein in the positive cases correlates with, or is 
driven by, a lack of GSTP1 CpG island hypermethylation. Additional studies are underway in our laboratory to determine the CpG methylation status of GSTP1 alleles in cases with positive staining.

Finally, the finding that GSTP1-positive prostate cancer subset is substantially over-represented among prostate cancers from Black compared to White men could be of importance from the standpoint of treatment of lethal prostate cancer, providing a potential biological underpinning, at least in part, for the observed disparate outcomes for Black men. In breast cancer, the presence or absence of GSTP1 expression predicts response to cytotoxic chemotherapy, particularly to the taxanes docetaxel and paclitaxel [58-61]. Forced expression of the enzyme in GSTP1-negative breast cancer cells confers docetaxel resistance [58]. In addition, an MCF-7 clone selected for taxane-resistance exhibited activation of GSTP1 expression [62]. Thus, the over-representation of GSTP1-positive prostate cancer in Black men may render them less responsive to taxane chemotherapy, which is the preferred chemotherapy for advanced, lethal metastatic castration resistant prostate cancer [5].

\section{Conclusion}

In summary, we systematically examined GSTP1 protein expression in a large number of primary prostatic adenocarcinomas and found an overall rate of positivity of $7.7 \%$, and a higher percentage of cases staining positive in Black men compared with cases from White men (2.53 fold). A significant difference in the percentages of GSTP1 positive cases in Black men was present only in ERG-positive cases, as compared with ERG-negative cases. These findings should stimulate additional studies regarding whether GSTP1 positive cases are a unique molecular and clinico-pathological subtype of human prostate cancer, with potential implications for disease etiology, racial disparities and therapeutic resistance mechanisms.

\section{Supporting information}

S1 Fig. GSTP1 IHC in prostate cancer cell lines. IHC was performed in the cell lines indicated. PC3 and DU145 cells are positive and LNCaP and MDA-PCa- $2 \mathrm{~b}$ are negative. (TIF)

\section{Author Contributions}

Conceptualization: William G. Nelson, Srinivasan Yegnasubramanian, Angelo M. De Marzo.

Data curation: Igor Vidal, Qizhi Zheng, Jessica L. Hicks, Jiayu Chen, Ibrahim Kulac, Javier A. Baena-Del Valle, Karen S. Sfanos, Sarah Ernst, Tracy Jones, Janielle P. Maynard, Stephanie A. Glavaris, Angelo M. De Marzo.

Formal analysis: Elizabeth A. Platz, Angelo M. De Marzo.

Funding acquisition: Angelo M. De Marzo.

Investigation: Igor Vidal, Qizhi Zheng, Jessica L. Hicks, Jiayu Chen, Elizabeth A. Platz, Bruce J. Trock, Ibrahim Kulac, Javier A. Baena-Del Valle, Tracy Jones, Stephanie A. Glavaris.

Methodology: Igor Vidal, Qizhi Zheng, Elizabeth A. Platz, Bruce J. Trock, Karen S. Sfanos, Angelo M. De Marzo.

Project administration: Karen S. Sfanos, Sarah Ernst, Tracy Jones, Stephanie A. Glavaris.

Supervision: Bruce J. Trock, Karen S. Sfanos, Angelo M. De Marzo.

Validation: Janielle P. Maynard. 
Writing - original draft: Igor Vidal, William G. Nelson, Srinivasan Yegnasubramanian, Angelo M. De Marzo.

Writing - review \& editing: Igor Vidal, Elizabeth A. Platz, Bruce J. Trock, Ibrahim Kulac, Javier A. Baena-Del Valle, Karen S. Sfanos, William G. Nelson, Srinivasan Yegnasubramanian, Angelo M. De Marzo.

\section{References}

1. Allocati N, Masulli M, Di llio C, Federici L. Glutathione transferases: substrates, inihibitors and prodrugs in cancer and neurodegenerative diseases. Oncogenesis. 2018; 7: 8. https://doi.org/10.1038/ s41389-017-0025-3 PMID: 29362397

2. Lee WH, Morton RA, Epstein JI, Brooks JD, Campbell PA, Bova GS, et al. Cytidine methylation of regulatory sequences near the pi-class glutathione $\mathrm{S}$-transferase gene accompanies human prostatic carcinogenesis. Proc Natl Acad Sci U S A. 1994; 91: 11733-11737. Available: https://www.ncbi.nlm.nih.gov/ pubmed/7972132. https://doi.org/10.1073/pnas.91.24.11733 PMID: 7972132

3. Lin X, Tascilar M, Lee WH, Vles WJ, Lee BH, Veeraswamy R, et al. GSTP1 CpG island hypermethylation is responsible for the absence of GSTP1 expression in human prostate cancer cells. Am J Pathol. 2001; 159: 1815-1826. https://doi.org/10.1016/S0002-9440(10)63028-3 PMID: 11696442

4. Yegnasubramanian S, De Marzo AM, Nelson WG. Prostate Cancer Epigenetics: From Basic Mechanisms to Clinical Implications. Cold Spring Harb Perspect Med. 2018. https://doi.org/10.1101/ cshperspect.a030445 PMID: 29959132

5. Nelson WG, Antonarakis ES, Balentine CH, De Marzo AM, Deweese TL. Prostate Cancer. Abeloff's Clinical Oncology, Sixth Edition. Elsevier, Inc; 2020. pp. 1401-1432. Available: https://wwwclinicalkey-com. proxy1.library.jhu.edu/\#!/content/book/3-s2.0-B9780323476744000815.

6. Brooks JD, Weinstein M, Lin X, Sun Y, Pin SS, Bova GS, et al. CG island methylation changes near the GSTP1 gene in prostatic intraepithelial neoplasia. Cancer Epidemiol Biomarkers Prev. 1998; 7: 531536. Available: https://www.ncbi.nlm.nih.gov/pubmed/9641498. PMID: 9641498

7. Nakayama M, Bennett CJ, Hicks JL, Epstein JI, Platz EA, Nelson WG, et al. Hypermethylation of the human glutathione S-transferase-pi gene (GSTP1) CpG island is present in a subset of proliferative inflammatory atrophy lesions but not in normal or hyperplastic epithelium of the prostate: a detailed study using laser-capture microdissection. Am J Pathol. 2003; 163: 923-933. Available: https://www. ncbi.nlm.nih.gov/pubmed/12937133. https://doi.org/10.1016/s0002-9440(10)63452-9 PMID: 12937133

8. Trabzonlu L, Kulac I, Zheng Q, Hicks JL, Haffner MC, Nelson WG, et al. Molecular Pathology of HighGrade Prostatic Intraepithelial Neoplasia: Challenges and Opportunities. Cold Spring Harb Perspect Med. 2018. https://doi.org/10.1101/cshperspect.a030403 PMID: 30082453

9. Mian OY, Khattab MH, Hedayati M, Coulter J, Abubaker-Sharif B, Schwaninger JM, et al. GSTP1 Loss results in accumulation of oxidative DNA base damage and promotes prostate cancer cell survival following exposure to protracted oxidative stress. Prostate. 2016; 76: 199-206. https://doi.org/10.1002/ pros.23111 PMID: 26447830

10. Henderson CJ, Smith AG, Ure J, Brown K, Bacon EJ, Wolf CR. Increased skin tumorigenesis in mice lacking pi class glutathione S-transferases. Proc Natl Acad Sci U S A. 1998; 95: 5275-5280. https://doi. org/10.1073/pnas.95.9.5275 PMID: 9560266

11. Ritchie KJ, Henderson CJ, Wang XJ, Vassieva O, Carrie D, Farmer PB, et al. Glutathione transferase pi plays a critical role in the development of lung carcinogenesis following exposure to tobacco-related carcinogens and urethane. Cancer Res. 2007; 67: 9248-9257. https://doi.org/10.1158/0008-5472.CAN07-1764 PMID: 17909032

12. Iwata T, Schultz D, Vaughn M, Yegnasubramanian S, Nelson WG, De Marzo AM. Glutathione S-transferase Pi (gstp1) Deficiency Accelerates Prostate Carcinogenesis In The Lo-myc Mouse. J Urol. 2009; 181: 183-184.

13. Townsend DM, Tew KD. The role of glutathione-S-transferase in anti-cancer drug resistance. Oncogene. 2003; 22: 7369-7375. https://doi.org/10.1038/sj.onc.1206940 PMID: 14576844

14. Satoh K, Kitahara A, Soma $Y$, Inaba $Y$, Hatayama I, Sato K. Purification, induction, and distribution of placental glutathione transferase: a new marker enzyme for preneoplastic cells in the rat chemical hepatocarcinogenesis. Proc Natl Acad Sci U S A. 1985; 82: 3964-3968. https://doi.org/10.1073/pnas.82.12. 3964 PMID: 3923485

15. Hayes JD, Pulford DJ. The glutathione S-transferase supergene family: regulation of GST and the contribution of the isoenzymes to cancer chemoprotection and drug resistance. Crit Rev Biochem Mol Biol. 1995; 30: 445-600. https://doi.org/10.3109/10409239509083491 PMID: 8770536 
16. Sailer V, Eberhard HLK, Stephan C, Wernert N, Perner S, Jung K, et al. Glutathione S-transferase-pi protein expression in prostate cancer-not always a useful diagnostic tool. Histopathology. 2015; 67: 577-579. https://doi.org/10.1111/his.12671 PMID: 25684637

17. Martignano F, Gurioli G, Salvi S, Calistri D, Costantini M, Gunelli R, et al. GSTP1 Methylation and Protein Expression in Prostate Cancer: Diagnostic Implications. Dis Markers. 2016; 2016: 4358292. https:// doi.org/10.1155/2016/4358292 PMID: 27594734

18. Smith ZL, Eggener SE, Murphy AB. African-American Prostate Cancer Disparities. Curr Urol Rep. 2017; 18: 81. https://doi.org/10.1007/s11934-017-0724-5 PMID: 28808871

19. Rosen P, Pfister D, Young D, Petrovics G, Chen Y, Cullen J, et al. Differences in frequency of ERG oncoprotein expression between index tumors of Caucasian and African American patients with prostate cancer. Urology. 2012; 80: 749-753. https://doi.org/10.1016/j.urology.2012.07.001 PMID: 22950997

20. Tosoian JJ, Almutairi F, Morais CL, Glavaris S, Hicks J, Sundi D, et al. Prevalence and Prognostic Significance of PTEN Loss in African-American and European-American Men Undergoing Radical Prostatectomy. Eur Urol. 2017; 71: 697-700. https://doi.org/10.1016/j.eururo.2016.07.026 PMID: 27477529

21. Yuan J, Kensler KH, Hu Z, Zhang Y, Zhang T, Jiang J, et al. Integrative comparison of the genomic and transcriptomic landscape between prostate cancer patients of predominantly African or European genetic ancestry. PLoS Genet. 2020; 16: e1008641. https://doi.org/10.1371/journal.pgen.1008641 PMID: 32059012

22. Koga $Y$, Song H, Chalmers ZR, Newberg J, Kim E, Carrot-Zhang J, et al. Genomic Profiling of Prostate Cancers from Men with African and European Ancestry. Clin Cancer Res. 2020. https://doi.org/10. 1158/1078-0432.CCR-19-4112 PMID: 32651179

23. Jamaspishvili T, Berman DM, Ross AE, Scher HI, De Marzo AM, Squire JA, et al. Clinical implications of PTEN loss in prostate cancer. Nat Rev Urol. 2018. https://doi.org/10.1038/nrurol.2018.9 PMID: 29460925

24. Chaux A, Peskoe SB, Gonzalez-Roibon N, Schultz L, Albadine R, Hicks J, et al. Loss of PTEN expression is associated with increased risk of recurrence after prostatectomy for clinically localized prostate cancer. Mod Pathol. 2012; 25: 1543-1549. https://doi.org/10.1038/modpathol.2012.104 PMID: 22684219

25. Hempel Sullivan H, Heaphy CM, Kulac I, Cuka N, Lu J, Barber JR, et al. High Extratumoral Mast Cell Counts Are Associated with a Higher Risk of Adverse Prostate Cancer Outcomes. Cancer Epidemiol Biomarkers Prev. 2020. https://doi.org/10.1158/1055-9965.EPI-19-0962 PMID: 31932412

26. Faith DA, Isaacs WB, Morgan JD, Fedor HL, Hicks JL, Mangold LA, et al. Trefoil factor 3 overexpression in prostatic carcinoma: prognostic importance using tissue microarrays. Prostate. 2004; 61: 215-227. https://doi.org/10.1002/pros.20095 PMID: 15368473

27. Gurel B, Iwata T, Koh CM, Jenkins RB, Lan F, Van Dang C, et al. Nuclear MYC protein overexpression is an early alteration in human prostate carcinogenesis. Mod Pathol. 2008; 21: 1156-1167. https://doi. org/10.1038/modpathol.2008.111111. PMID: 18567993

28. Baena-Del Valle JA, Zheng Q, Hicks JL, Fedor H, Trock BJ, Morrissey C, et al. Rapid Loss of RNA Detection by In Situ Hybridization in Stored Tissue Blocks and Preservation by Cold Storage of Unstained Slides. Am J Clin Pathol. 2017; 148: 398-415. https://doi.org/10.1093/ajcp/aqx094 PMID: 29106457

29. Holdhoff M, Guner G, Rodriguez FJ, Hicks JL, Zheng Q, Forman MS, et al. Absence of Cytomegalovirus in Glioblastoma and Other High-grade Gliomas by Real-time PCR, Immunohistochemistry, and In Situ Hybridization. Clin Cancer Res. 2017; 23: 3150-3157. https://doi.org/10.1158/1078-0432.CCR-161490 PMID: 28034905

30. Chen J, Zheng Q, Peiffer LB, Hicks JL, Haffner MC, Rosenberg AZ, et al. An in situ atlas of mitochondrial DNA in mammalian tissues reveals high content in stem/progenitor cells. Am J Pathol. 2020. https://doi.org/10.1016/j.ajpath.2020.03.018 PMID: 32304697

31. Lotan TL, Gurel B, Sutcliffe S, Esopi D, Liu W, Xu J, et al. PTEN protein loss by immunostaining: anaIytic validation and prognostic indicator for a high risk surgical cohort of prostate cancer patients. Clin Cancer Res. 2011; 17: 6563-6573. https://doi.org/10.1158/1078-0432.CCR-11-1244 PMID: 21878536

32. Toubaji A, Albadine R, Meeker AK, Isaacs WB, Lotan T, Haffner MC, et al. Increased gene copy number of ERG on chromosome 21 but not TMPRSS2-ERG fusion predicts outcome in prostatic adenocarcinomas. Mod Pathol. 2011; 24: 1511-1520. https://doi.org/10.1038/modpathol.2011.111 PMID: 21743434

33. Tan H-L, Haffner MC, Esopi DM, Vaghasia AM, Giannico GA, Ross HM, et al. Prostate adenocarcinomas aberrantly expressing $\mathrm{p} 63$ are molecularly distinct from usual-type prostatic adenocarcinomas. Mod Pathol. 2015; 28: 446-456. https://doi.org/10.1038/modpathol.2014.115 PMID: 25216229 
34. Jiang Z, Li C, Fischer A, Dresser K, Woda BA. Using an AMACR (P504S)/34betaE12/p63 cocktail for the detection of small focal prostate carcinoma in needle biopsy specimens. Am J Clin Pathol. 2005; 123: 231-236. https://doi.org/10.1309/1g1nk9dbgfnb792I PMID: 15842047

35. Furusato B, Tan S-H, Young D, Dobi A, Sun C, Mohamed AA, et al. ERG oncoprotein expression in prostate cancer: clonal progression of ERG-positive tumor cells and potential for ERG-based stratification. Prostate Cancer Prostatic Dis. 2010; 13: 228-237. https://doi.org/10.1038/pcan.2010.23 PMID: 20585344

36. Chaux A, Albadine R, Toubaji A, Hicks J, Meeker A, Platz EA, et al. Immunohistochemistry for ERG expression as a surrogate for TMPRSS2-ERG fusion detection in prostatic adenocarcinomas. Am J Surg Pathol. 2011; 35: 1014-1020. https://doi.org/10.1097/PAS.0b013e31821e8761 PMID: 21677539

37. Tomlins SA, Alshalalfa M, Davicioni E, Erho N, Yousefi K, Zhao S, et al. Characterization of 1577 primary prostate cancers reveals novel biological and clinicopathologic insights into molecular subtypes. Eur Urol. 2015; 68: 555-567. https://doi.org/10.1016/j.eururo.2015.04.033 PMID: 25964175

38. Baydar DE, Kulac I, Gurel B, De Marzo A. A case of prostatic adenocarcinoma with aberrant p63 expression: presentation with detailed immunohistochemical study and FISH analysis. Int J Surg Pathol. 2011; 19: 131-136. https://doi.org/10.1177/1066896910379478 PMID: 20719821

39. Giannico GA, Ross HM, Lotan T, Epstein Jl. Aberrant expression of p63 in adenocarcinoma of the prostate: a radical prostatectomy study. Am J Surg Pathol. 2013; 37: 1401-1406. https://doi.org/10.1097/ PAS.0b013e31828d5c32 PMID: 23774168

40. Torres A, Alshalalfa M, Davicioni E, Gupta A, Yegnasubramanian S, Wheelan SJ, et al. ETS2 is a prostate basal cell marker and is highly expressed in prostate cancers aberrantly expressing p63. Prostate. 2018. https://doi.org/10.1002/pros.23646 PMID: 29761525

41. De Marzo AM, Marchi VL, Epstein JI, Nelson WG. Proliferative inflammatory atrophy of the prostate: implications for prostatic carcinogenesis. Am J Pathol. 1999; 155: 1985-1992. https://doi.org/10.1016/ S0002-9440(10)65517-4 PMID: 10595928

42. Zha S, Yegnasubramanian V, Nelson WG, Isaacs WB, De Marzo AM. Cyclooxygenases in cancer: progress and perspective. Cancer Lett. 2004; 215: 1-20. https://doi.org/10.1016/j.canlet.2004.06.014 PMID: 15374627

43. Robinson D, Van Allen EM, Wu Y-M, Schultz N, Lonigro RJ, Mosquera J-M, et al. Integrative Clinical Genomics of Advanced Prostate Cancer. Cell. 2015; 162: 454. https://doi.org/10.1016/j.cell.2015.06. 053 PMID: 28843286

44. Cancer Genome Atlas Research Network. The Molecular Taxonomy of Primary Prostate Cancer. Cell. 2015; 163: 1011-1025. https://doi.org/10.1016/j.cell.2015.10.025 PMID: 26544944

45. Armenia J, Wankowicz SAM, Liu D, Gao J, Kundra R, Reznik E, et al. The long tail of oncogenic drivers in prostate cancer. Nat Genet. 2018; 1. https://doi.org/10.1038/s41588-017-0017-4 PMID: 29273803

46. Quigley DA, Dang HX, Zhao SG, Lloyd P, Aggarwal R, Alumkal JJ, et al. Genomic Hallmarks and Structural Variation in Metastatic Prostate Cancer. Cell. 2018; 174: 758-769.e9. https://doi.org/10.1016/j. cell.2018.06.039 PMID: 30033370

47. Wu Y-M, Cieślik M, Lonigro RJ, Vats $P$, Reimers $M A$, Cao X, et al. Inactivation of CDK12 Delineates a Distinct Immunogenic Class of Advanced Prostate Cancer. Cell. 2018; 173: 1770-1782.e14. https://doi org/10.1016/j.cell.2018.04.034 PMID: 29906450

48. Viswanathan SR, Ha G, Hoff AM, Wala JA, Carrot-Zhang J, Whelan CW, et al. Structural Alterations Driving Castration-Resistant Prostate Cancer Revealed by Linked-Read Genome Sequencing. Cell. 2018. https://doi.org/10.1016/j.cell.2018.05.036 PMID: 29909985

49. Ganaie AA, Beigh FH, Astone M, Ferrari MG, Maqbool R, Umbreen S, et al. BMl1 Drives Metastasis of Prostate Cancer in Caucasian and African-American Men and Is A Potential Therapeutic Target: Hypothesis Tested in Race-specific Models. Clin Cancer Res. 2018; 24: 6421-6432. https://doi.org/10. 1158/1078-0432.CCR-18-1394 PMID: 30087142

50. Rebbeck TR. Prostate Cancer Disparities by Race and Ethnicity: From Nucleotide to Neighborhood. Cold Spring Harb Perspect Med. 2018;8. https://doi.org/10.1101/cshperspect.a030387 PMID: 29229666

51. Wallace TA, Prueitt RL, Yi M, Howe TM, Gillespie JW, Yfantis HG, et al. Tumor immunobiological differences in prostate cancer between African-American and European-American men. Cancer Res. 2008; 68: 927-936. https://doi.org/10.1158/0008-5472.CAN-07-2608 PMID: 18245496

52. Reams RR, Renee Reams R, Agrawal D, Davis MB, Yoder S, Odedina FT, et al. Microarray comparison of prostate tumor gene expression in African-American and Caucasian American males: a pilot project study. Infectious Agents and Cancer. 2009. https://doi.org/10.1186/1750-9378-4-S1-S3 PMID: 19208208 
53. Powell IJ, Dyson G, Land S, Ruterbusch J, Bock CH, Lenk S, et al. Genes associated with prostate cancer are differentially expressed in African American and European American men. Cancer Epidemiol Biomarkers Prev. 2013; 22: 891-897. https://doi.org/10.1158/1055-9965.EPI-12-1238 PMID: 23515145

54. Maynard JP, Ertunc O, Kulac I, Baena-Del Valle JA, De Marzo AM, Sfanos KS. IL8 Expression Is Associated with Prostate Cancer Aggressiveness and Androgen Receptor Loss in Primary and Metastatic Prostate Cancer. Mol Cancer Res. 2020; 18: 153-165. https://doi.org/10.1158/1541-7786.MCR-190595 PMID: 31604846

55. De Marzo AM, Platz EA, Sutcliffe S, Xu J, Grönberg H, Drake CG, et al. Inflammation in prostate carcinogenesis. Nat Rev Cancer. 2007; 7: 256-269. https://doi.org/10.1038/nrc2090 PMID: 17384581

56. Sfanos KS, Yegnasubramanian S, Nelson WG, De Marzo AM. The inflammatory microenvironment and microbiome in prostate cancer development. Nat Rev Urol. 2017. https://doi.org/10.1038/nrurol 2017.167 PMID: 29089606

57. Liu X, Grogan TR, Hieronymus H, Hashimoto T, Mottahedeh J, Cheng D, et al. Low CD38 Identifies Progenitor-like Inflammation-Associated Luminal Cells that Can Initiate Human Prostate Cancer and Predict Poor Outcome. Cell Rep. 2016; 17: 2596-2606. https://doi.org/10.1016/j.celrep.2016.11.010 PMID: 27926864

58. Iwao-Koizumi K, Matoba R, Ueno N, Kim SJ, Ando A, Miyoshi Y, et al. Prediction of docetaxel response in human breast cancer by gene expression profiling. J Clin Oncol. 2005; 23: 422-431. https://doi.org/ 10.1200/JCO.2005.09.078 PMID: 15659489

59. Arai T, Miyoshi Y, Kim SJ, Akazawa K, Maruyama N, Taguchi T, et al. Association of GSTP1 expression with resistance to docetaxel and paclitaxel in human breast cancers. Eur J Surg Oncol. 2008; 34: 734738. https://doi.org/10.1016/j.ejso.2007.07.008 PMID: 17764884

60. Miyake T, Nakayama T, Naoi Y, Yamamoto N, Otani Y, Kim SJ, et al. GSTP1 expression predicts poor pathological complete response to neoadjuvant chemotherapy in ER-negative breast cancer. Cancer Science. 2012. pp. 913-920. https://doi.org/10.1111/j.1349-7006.2012.02231.x PMID: 22320227

61. Eralp Y, Keskin S, Akisik E, Akisik E, Igci A. Predictive role of midtreatment changes in survivin, GSTP1, and topoisomerase $2 \alpha$ expressions for pathologic complete response to neoadjuvant .... American journal of. 2013. Available: https://journals.Iww.com/amjclinicaloncology/fulltext/2013/06000/ Predictive_Role_of_Midtreatment_Changes_in.1.aspx.

62. Işeri OD, Kars MD, Gündüz U. Two different docetaxel resistant MCF-7 sublines exhibited different gene expression pattern. Mol Biol Rep. 2012; 39: 3505-3516. https://doi.org/10.1007/s11033-0111123-5 PMID: 21720762 